\title{
Pembelajaran dan Pemberdayaan Masyarakat melalui Pengajaran Calistung bagi Warga Distrik Bamusbama, Kabupaten Tambrauw, Papua Barat
}

\author{
Heriyanti Tahang ${ }^{1}$, Rahmatullah Bin Arsyad ${ }^{2}$ dan Ihsan Febriadi ${ }^{3}$ \\ ${ }^{1}$ Pendidikan Bahasa Inggris, Fakultas Keguruan dan Ilmu Pendidikan, Universitas Muhammadiyah \\ Sorong \\ ${ }^{2}$ Pendidikan Matematika, Fakultas Keguruan dan Ilmu Pendidikan, Universitas Muhammadiyah \\ Sorong \\ ${ }^{3}$ Kehutanan, Fakultas Pertanian, Universitas Muhammadiyah Sorong \\ ${ }^{1}$ heriyantitahang@um-sorong.ac.id \\ ${ }^{2}$ ihsanfebriadi84@um-sorong.ac.id \\ ${ }^{3}$ rahmatullahbinarsyad@gmail.com
}

\begin{abstract}
ABSTRAK
Kabupaten Tambrauw sebagai kabupaten dengan jumlah buta aksara tertinggi di Papua Barat menjadikan kegiatan Pembelajaran dan Pemberdayaan masyarakat melalaui pembelajaran Calistung perlu dilakukan. Kampung Bano menjadi lokasi pembelajaran karena jaraknya dengan Kota Kabupaten yang cukup jauh. Berdasar pada data terbaru distrik Bamusbama, 72\% masyarakat kampung Bano tidak mengenyam pendidikan. Hal tersebut tentunya berbanding sama dengan kemampuan calistung yang dimilki masyarakat. Untuk mengatasi hal tersebut, KKN-PPM dengan 20 mahasiswa UM-Sorong melalui hibah Kemenristek Dikiti dilakukan dengan kegiatan pembelajaran Calistung. Sebelum pembelajaran dimulai, sosialisasi kepada masyarakat dilakukan. Setelah itu dilakukan pemetaan potensi lokal guna mendukung pembelajaran calistung. Selanjutnya kontrak belajar dilakukan guna menyepakati jadwal kegiatan. Setelah itu dilakukan pre-test guna mengetahui kemampuan awal masyarakat. Pembelajarn selama lima kali seminggu disesuaikan dengan kegiatan rutin masyarakat. Sebelum proses pembelajaran berakhir, dilakukan post-test untuk mengetahui peningkatan pengetahuan masyarakat setelah pembelajaran. Hasil pre-test dan post-test menunjukan peningkatan pengetahuan masyarakat, dari $17 \%$ hingga $89 \%$ untuk membaca, kemampuan memnulis dari $28 \%$ menjadi $89 \%$, dan untuk kemampuan berhitung meningkat dari $17 \%$ hingga $44 \%$. Kemampuan Calistung yang dimiliki oleh masyarakat masih tergolong kemampuan dasar hingga masih perlu keberlanjutan pembelajaran. Hingga melalui KKN-PPM ini telah dipilih dua peserta sebagai tutor yang akan melanjutkan kegiatan pembelajaran Calistung di Kampung Bano.
\end{abstract}

Kata kunci: Pembelajaran Calistung, Bamusbama, Kabupaten Tambrauw

\begin{abstract}
Tambrauw Regency as the highest number of illiterates in West Papua makes community learning and empowerment activity through learning Calistung needed. Bano village is choosen because of its distance from the city that is quite far. Based on the newest data of Bamusbama Distrik, $72 \%$ of Bano villagers have no education. This is certainly paralleled to the Calistung ability of the villagers. To overcome the problem, KKN-PPM with 20 students of UM-Sorong through grant of Kemenristek Dikti is conducted by Calistung teaching and learning process. Before beginning the process, Socialization to the Villagers is carried out. Then a mapping of local potential is done to support the learning process. After that, the learning schedule agreed with the villagers. Before beginning the lesson, pretest was conducted to now the participants' base understanding. The teaching and learning process are conducted five times a week adapted to villagers' daily routine. After the learning proses, Participants are also given a post-test to know their final understanding after the lesson. The result shows that reading competence was risen from 17\% to $89 \%, 28 \%$ to $89 \%$ for writing ability, and improved from $17 \%$ to $44 \%$ for participants' ability to count. The participants' competence is still under average. So, it still need improvement. Two participants were chosen as the Tutor in order to continue this Calistung learning activity for e better improvement in kampung Bano.
\end{abstract}

Key Words: Calistung Learning, Bamusbama, Tambrauw Regency 


\section{PENDAHULUAN}

Pendidikan hingga saat ini masih menjadi fokus utama Bangsa Indonesia. Pendidikan menjadi tolak ukur kemampuan masyarakat dalam menjalani kehidupan yang lebih baik, khususnya daerah $3 \mathrm{~T}$. Hal ini dijelaskan oleh pihak kemedikbud melalui laman webnya, bahwa kemendikbud telah merusmuskan upaya pemberantasan buta aksara dengan memprioritaskan, (1), daerahdaerah "merah" yang memiliki angka buta aksara di atas 4\%, (2) Komunitas adat khusus/terpencil, (3) Daerah tertinggal, terdepan, dan terluar (3T).

Kabupaten Tambrauw selain menjadi daerah 3T, Tambrauw juga merupakan salah satu Kabupaten yang memiliki jumlah penduduk dengan Buta aksara yang cukup tinggi di Papua Barat. Hal ini dijelaskan oleh Yohana sebagai salah seorang pelopor tim pemberantasan buta aksara di kabupaten Tambrauw dilansir dalam Redaksi Papua bahwa sebagian besar penduduk Tambrauw selain tidak bisa Calistung mereka juga tidak memiliki kemampuan berkomunikasi yang baik.

Sebelumnya telah terbentuk tim Pusat Kegiatan Belajar Mengajar (PKBM) yang mengajar 60 Peserta dari jenjang usia 15-59 tahun yang tersebar di empat kampung yaitu Yokje, Emaus, Bondegwan dan Bonde (Redaksi Kobar Papua). Selain itu, pihak pemerintah melalui Dinas Pendidikan telah berupaya dalam pemberantasan buta aksara dengan membentuk 6 PKBM yang berpusat di ibu kota Kabupaten Tambrauw, Sausapor.

Berdasarkan data distrik Bamusbama terbaru 2019, sebanyak $72 \%$ masyarakat Kampung Bano Distrik Bamusbama tidak mengenyam pendidikan sekolah. Hal ini menunjukkan bahwa buta aksara memang sangat besar di kampung tersebut. Hal ini juga dibuktikan oleh data awal pre-test untuk mengukur kemampuan Calistung Masyarakat yang tergabung dalam kelas pembelajaran calistung kelas kampung Bano, hanya terdapat kurang lebih 6\% masyarakat yang mampu Calistung dengan kemampuan yang masih terbata-bata dalam membaca menulis dan menghitung sederhana dengan bantuan alat.

Masyarakat Kampung Bano dipilih karena lokasinya yang berjarak sangat jauh dari Kota Kabupaten dengan jarak tempuh \pm 4 jam dengan kecepatan $80 \mathrm{~km} / \mathrm{jam}$ menggunakan mobil dobel kabin dengan biaya sewa Mobil yang cukup Mahal yaitu $\pm \mathrm{Rp}$.
2500.000. per satu kali jalan. Di Kampung tersebut juga belum terbentuk tim PKBM sebagai tempat masyarakat belajar Calistung.

Masyarakat di Kampung Bano merupakan masyarakat yang bekerja sebagai Petani dan Pekebun. Masyarakat umumnya masih menggunakan Bahasa Daerah dalam percapakan sehari-harinya sehingga kemampuan berkomunikasi dalam Bahasa Indonesia masih sangat kurang. Kurangnya kemampuan Calistung mengakibatkan hasil kebun dan Pertanian belum dipasarkan secara luas hingga luar Kabupaten Tambrauw. Seperti yang ditulis oleh wahyuni dalam artikelnya, bahwa kemampuan aksara, menulis dan membaca merupakan modal dasar untuk berkomunikasi dijaman modern saat ini. Jadi tingginya angka buta aksara tersebut harus segera diatasi.

Berdasar pada paparan sebelumnya, melalui Kegiatan KKN-PPM dilakukan Pembelajaran Calistung di Kampung Bano guna meningkatkan minimal satu pengetahuan masyarakat dalam membaca, menulis dan menghitung. Melalui pembelajaran ini pula akan dipilih calon tutor yang mampu melanjutkan kegiatan pembelajaran secara mandiri setelah kegiatan pembelajaran selesai.

Berdasar pada uraian diatas, telah dirumuskan permasalahan berikut (1). Masyarakat Kampung Bano perlu meningkatkan pengetahuan dan kemampuan Calistung demi peningkatan kehidupan yang lebih baik. (2).Perlunya Tutor yang mampu Calistung secara mandiri yang akan melanjutkan pembelajaran Calistung sebagai upaya pembelajaran dan pemberdayaan masyarakat secara berkesinambungan.

\section{METODE KEGIATAN}

Metode Pelaksanaan yang dilakukan dalam Pembelajaran dan Pemberdayaan Masyarakat melalui Pengajaran Calistung bagi Warga Kampung Bano, Distrik Bamusbama, Kabupaten Tambrauw, Papua Barat adalah sebagai berikut:

\section{Persiapan}

Pada tahapan ini, dilakukan Sosialisasi

Kegiatan kepada seluruh mahasiswa UMSorong yang akan memprogramkan KKN agar dapat mengikuti KKN-PPM di Kabupaten Tambrauw. Setelah itu dilakukan identifikasi awal dan pemetaan sasaran program dengan mewawancarai pegawai Distrik Bmusbama, 
Kabuapten Tambrauw. Selanjutnya dilakukan Pembekalan kepada 20 Mahasiswa yang akan membantu dalam proses pembelajaran Calistung yang dilakukan di Kampung Bano, Distrik Bamusbama, Kabupaten Tambrauw.

2. Pelaksanaan

Sebelum melakasanakan pembelajaran Calistung, Sosialisasi kepada Masyarakat serta identifikasi tema-tema local sebagai sumber belajar dilakukan, seperti memahami kondisi dan keadaan sekitar masyrakat guna mendukung proses belajar mengajar Calistung. Setelah itu kontrak belajar dengan peserta dilakukan guna menyesuaikan jadwal pembelajaran.

Selanjutnya tim melakukan penyusunan program belajar yang disesuaikan dengan hasil pre-test yang telah diperoleh. Pemilihan mtode pembelajaran juga dilakukan demi menyesuaikan proses pembelajaran dengan kebutuhan peserta. Setelah semua proses awal pelaksanaan selesai, pelaksanaan proses belajar mengajar dilakukan sesuai dengan jadwal kontrak belajar yang telah disepakati sebelumnya.

Selanjutnya untuk mengetahui evaluasi akhir, dilakukan Post-test Calistung guna mengetahui kemampuan akhir peserta. Untuk mengetahui jumlah peserta yang mampu Calistung pada tahap awal (Pre-test) dan akhir (Post-test) digunakan perhitungan berikut:

Jumlah Peserta yang Mampu Calistung

$\frac{\text { Jumlah Peserta Pembelajaran Calistung }}{\times 100}$

Kegiatan Pembelajaran dan Pemberdayaan masyarakat ini terselenggara atas dukungan Kemenristek Dikti melalui Hibah Pengabdian Masyarakat 2019. Kegiatan ini dilakukan Bersama 20 Mahasiswa/I Universitas Muhammadiyah Sorong beserta 3 Dosen pembimbing lapangaan. Tentunya kegiatan ini juga sangat didukung oleh Pemerintah Kabupaten Tambrauw Provinsi Papua Barat, distrik Bamusbama hingga Kepala Kampung.

HASIL \& PEMBAHASAN
Sebelum melaksanakan kegiatan pembelajaran Calistung, sosialisasi dilakukan di kantor Distrik Bamusbama dengan menghadirkan Kepala Distrik beserta jajaran, Kepala Kampung, Tokoh Masyarakat, dan masyarakat kampung khususnya Kampung Bano. Setelah itu, di tempat yang sama dilakukan diskusi ringan dengan masyarakat guna mengidentifikasi tema-tema lokal yang sesuai dengan proses pembelajaran yang akan dilakukan, seperti mengetahui kebiasaan masyarakat yang tinggal di Kampung tersebut.

Sebelum memulai pembelajaran, kontrak belajar disepakati terlebih dahulu Bersama masyarakat pembelajar. Setelah kontrak belajar disepakati bersama, selanjutnya tim menyususn rencana belajar awal dalam breafing malam hari sebelum esoknya diaplikasikan, materi Calistung tentunya disesuikan dengan hasil pre-est dengan membagi kelas menjadi dua, kelas Private untuk yang belum memiliki dasar dan kemampuan Calistung, dan kelas lainnya bagi yang sudah memiliki dasar dan atau yang memiliki daya tangkap yang lebih baik. Selanjutnya Pembelajaran dilakukan selama lima kali seminggu dan jumlah pertemuan ini juga disesuaikan dengan kegiatan rutin masyarakat, mulai jam 8.00 pagi hingga 9.30 atau 10.00 pagi disesuikan dengan Kondisi Peserta saat proses pembelajaran. Demi meningkatkan motivasi pembelajaran, pembagian makanan ringan dilakukan tiap kali pertemuan. Pembelajaran dilakukan di balai Kampung Bano, Distrik Bamusbama, Kabupaten Tambrauw, Papua Barat.

Motode pembelajaran yang dipilih pun berganti-ganti sesuai dengan situasi dan kondisi kelas. Umumnya menggunakan Pendekatan Komunikatif, Face to Face, Bermain sambal belajar dan tentunya menggunakan media pembelajaran yang sederhana dengan menggunakan kosakata sederhana yang difahami masyarakat.

Monitoring dan Evaluasi senantiasa dilakukan tiap malam sebelum pelaksanaan pembelajaran guna memetakan dan mengetahui peningkatan kemampuan peserta serta guna mencari solusi permasalahan pembelajaran jika dibutuhkan.

Hasil pre-test dan post-test menunjukkan hasil yang cukup memuaskan, terdapat setidaknya 1 peningkatan pengetahuan bagi masing-masing peserta yang mengikuti program. Hasil peningkatan pembelajaran Calistung dibagi dalam tiga bagian yaitu kemampuan membaca, menulis dan kemampuan menghitung. Keamampuan membaca bedasar hasil pre-test adalah terdapat hanya $17 \%$ atau 3 peserta yang mampu membaca dengan kemampuan yang sangat terbata-bata dalam membaca suku kata, sedangkan pada hasil post-test terjadi peningkatan hingga $89 \%$ yaitu 16 peserta yang mamapu membaca secara umum menggunakan kosa kata sederhana dngan satu atau dua suku 
kata. Selanjutnya hasil pre-test pada kemampuan menulis menunjukkan bahwa terdapat $28 \%$ atau 5 peserta yang mampu menulis dengan cara meniru tulisan yang telah diberikan, hingga pada post-test ditunjukkan hasil yang signifikan yaitu sekitar $89 \%$ yaitu 16 peserta mampu menulis dengan meniru dan sebagian tanpa melihat teks. Sedang untuk hasil pre-test kemampuan berhitung menunjukkan hasil yang berbeda dengan dua kemampuan sebelumnya, hasil pre-test menunjukkan hanya terdapat 3 peserta atau $17 \%$ yang mampu menghitung dengan bantuan tangan atau alat lainnya, pada hasil post-test menunjukkan sedikit peningkatan yaitu menjadi $44 \%$ atau menjadi 8 peserta yan mampu menghitung dan 3 peserta sebelumnya sudah mampu menghitumg tanpa menggunakan bantuan lagi.

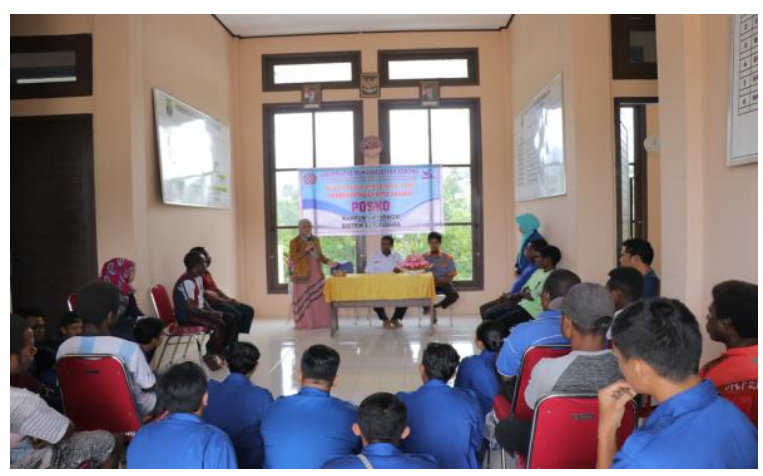

Gambar 1. Sosialisasi Kegiatan
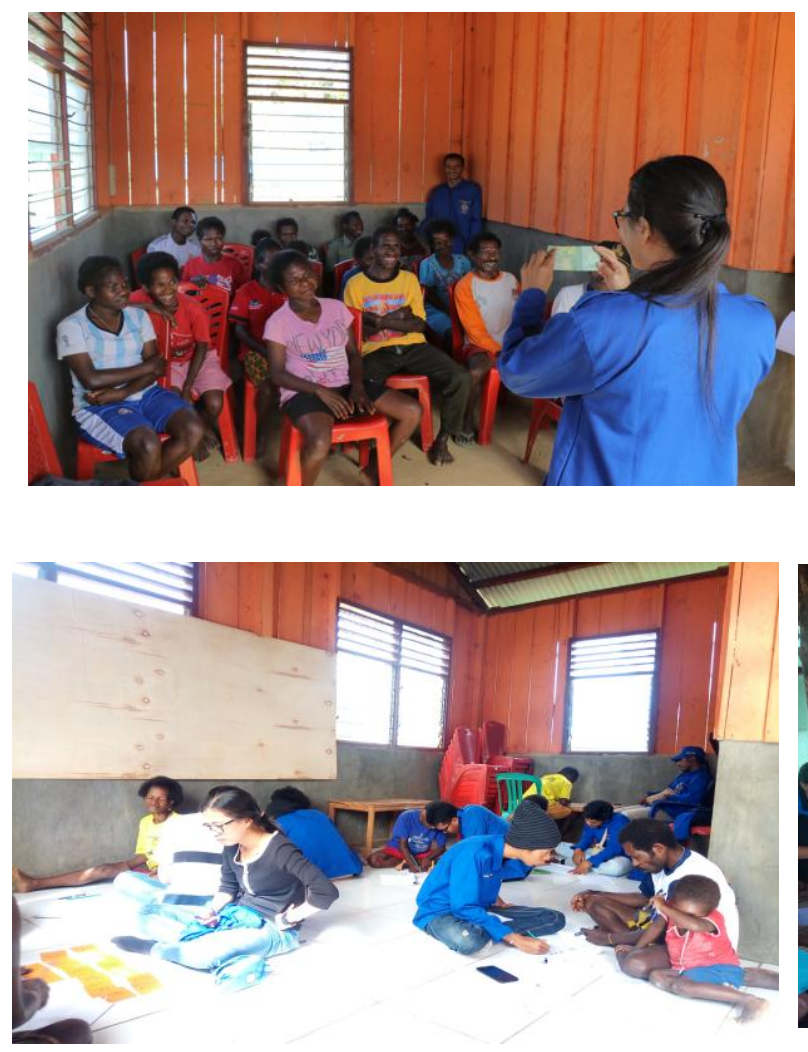

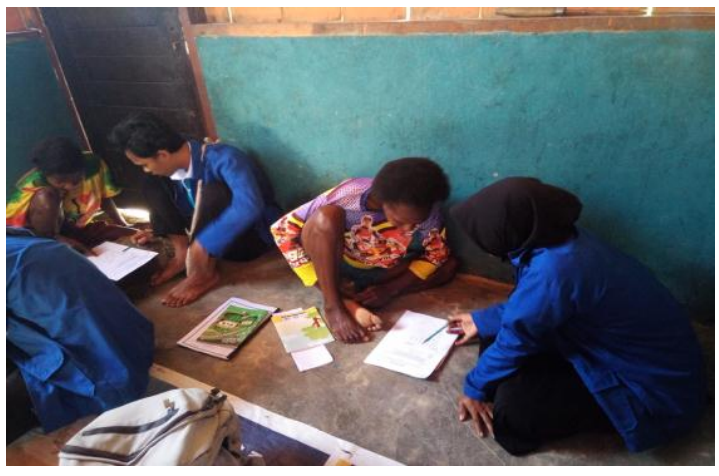

Gambar 1. Pre-test
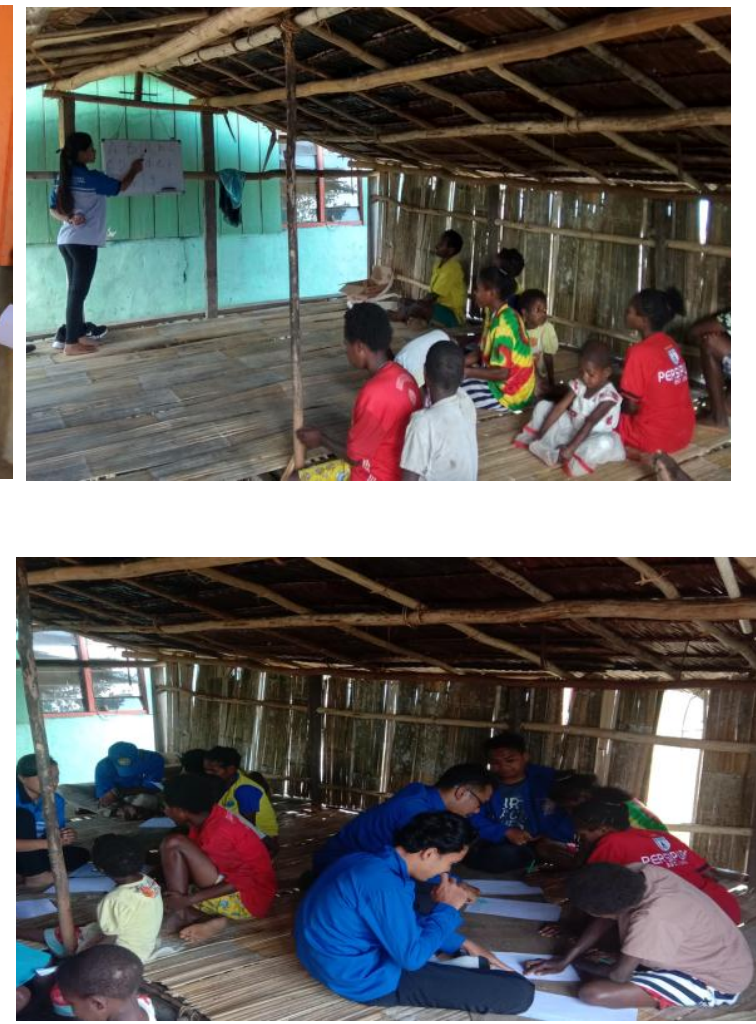

Gambar 3. Pembelajaran Calistung

Proses belajar mengajar Calistung di kampung Bano memang diakui masih memiliki beberapa kendala dalam proses pelaksanaannya. Masih rendahnya motivasi warga dalam belajar dan kesibukan berkebun serta Bertani menjadi tantangan tersendiri dalam pelaksanaan kegiatan ini. Tetapi dengan usaha dan kerja keras semua proses kegiatan Pembelajaran Calistung di kampung Bano distrik Bamusbama kabupaten Tambrauw 
berjalan dengan baik. Tentunya dengan dukungan Distrik dan Kepala Kampung yang sangat antusias dalam membantu proses belajar mengajar dengan menyediakan balai kampung sebagai tempat belajar masyarakat.

Selanjutnya telah dipilih dua calon tutor yang telah diberi sertifikat, Dorkas Yeblo dan Marce, yang akan melanjutkan kegiatan Pembelajaran Calistung guna mendukung keberlanjutan kegiatan ini. Kedua tutor tersebut sudah mampu membaca, menulis dan menghitung secra mandiri. Kebutuhan proses belajar mengajar juga telah dihibahkan guna mendukung fasilitas pembelajaran yang akan dilakukan berikutnya.

\section{KESIMPULAN \& SARAN}

Pembelajaran dan pemberdayaan masyarakat yang dilakukan melelui pembelajaran Membaca, Menulis dan Menghitung telah meningkatkan minimal satu pengetahuan masyarakat. Hal ini ditunjukkan dari hasil pre-test dan post-test. Perbedaan hasil pre-test dan post-test menunjukkan kemampuan Membaca masyarakat meningkat dari $17 \%$ menjadi $89 \%$ peserta dengan kemampuan membaca yang masih tegrolong dasar yaitu suku kata dan kata-kata sederhana. Kemampuan menulis pun menunjukkan peningkatan yang signifikan yaitu $28 \%$ menjadi $89 \%$ peserta dengan kemampuan menulis dengan meniru. Adpaun kemampuan menghitung tergolong masih memerlukan perhatian lebiah dari kemampuan lainnya karena hanya memiliki peningkatan dari $17 \%$ menjadi $44 \%$ peserta yang mampu menghitung dengan atau tanpa bantuan alat hitung.

Dua peserta yang mampu Calistung secara mandiri telah dipilih untuk menjadi tutor di kampung tersebut guna melanjutkan proses belajar mengajar yang telah dilakukan demi meningkatkan kemampuan mayarakat dalam Membaca, Menulis dan Menghitung.

Kegiatan ini perlu dilanjutkan oleh pemerintah Distrik Bamusbama, khususnya Kepala Kampung Bano minimal satu minggu sekali di balai kampung. Tak kalah penting, meningkatkan kesadaran masyarakat untuk belajar membaca dan menghitung juga sangat dibutuhkan guna mempercepat peningkatan kemampuan calistung masyarakat melalui pembelajaran calistung di kampung tersebut. Karena kamampuan calistung sangat bermanfaat dalam meningkatkan kemampuan komunikasi masyarakat dan tentunya akan berdampak pada pemesaran hasil kebun dan pertanian yang masayrakat hasilkan.
Ucapan terima kasih kepada Direktorat Riset dan Pengabdian Masyarakat, Direktorat Jenderal Penguatan Riset dan Pengembangan Kementrian Riset, Teknologi, dan Pendidikan Tinggi Republik Indonesia karena telah mendanai KKN-PPM ini melalui hibah kompetitif nasional Pendanaaan 2019.

\section{DAFTAR PUSTAKA}

Biro Komunikasi dan Layanan Masyarakat Kementrian Pendidikan dan Kebudayaan. Indonesia Peringati Hari Aksara Internasional Tahun 2019. 4 September 2018. https://www.kemdikbud.go.id/main/blog /2018/09/indonesia-peringati-hariaksara-internasional-tahun-2018 diakses pada hari Minggu 25 Agustus 2019 Pukul 13.30 WIT.

Data Distrik Bamusbama, Kabupaten Tambrauw 2019

Diana wahyuni. 2017. Tingginya Tingkat Buta Huruf di Indonesia. Kompasian. https://www.kompasiana.com/diana99/5 901d7e0db22bdb5148b4567/tingginyatingkat-buta-huruf-diindonesia?page $=$ all diakses pada hari minggu 25 Agustus 2019 pukul 13.00 WIT

Redaksi Kobar Papua. Delapan Pusat Kegiatan Belajar Masyarakat (PKBM) Siap Berantas Buta Aksara. Kobar Papua. 2 November 2017. Diakses di https://kobarpapua.com/breakingnews/delapan-pusat-kegiatan-belajarmasyarakat-pkbm-siap-berantas-butaaksara/ diakses pada hari minggu 25 Agustus 2019 pukul 12.00 WIT

Redaksi Kobar Papua. Tingkat Buta Aksara di Kabupaten Tambrauw Sangat Tinggi. Kobar Papua: 2 November 2017. https://kobarpapua.com/breakingnews/tingkat-buta-aksara-di-kabupatentambrauw-sangat-tinggi/ diakses pada hari minggu 25 Agustus 2019 pukul 14.30 WIT 